\title{
WOMEN IN THE QUEENSLAND LEGAL WORKPLACE: A SNAPSHOT
}

\author{
TERRY Hutchinson ${ }^{*}$ AND HeATHer SKOUSgaARD ${ }^{* *}$
}

\begin{abstract}
In addition to collating details of the demographic and working habits of over 2500 QLS members, the Queensland Law Society's Equalising Opportunities in the Law Committee 2003 Membership Survey Report focused on the nature and prevalence of discrimination and harassment in the Queensland legal workplace. Primary areas of concern to the respondents included discrimination or harassment on the basis of gender, age, family responsibilities, pregnancy and marital status. The results of this survey firmly demonstrate that promoting diversity in the Queensland legal workplace should be made a priority. Efforts to amend the Law Council of Australia Model Conduct Rules are ongoing. Providing this is done, will it be sufficient? What else needs to be changed to improve the situation and improve opportunities for diversity in the legal profession?
\end{abstract}

\section{INTRODUCTION}

Despite growing recognition of the importance of diversity and equal opportunity in the legal workplace, specific provisions covering discrimination, sexual harassment and workplace bullying are absent from the Queensland Rules of Professional Conduct. The results from the Queensland Law Society's Equalising Opportunities in the Law Committee 2003 Membership Survey suggest that the following two related issues should be given greater priority: first, the need for a more inclusive work environment, and, second, the need to foster an awareness of discrimination, harassment and bullying in the workplace. ${ }^{1}$ In addition to collating details of the demographic and working habits of over 2500 Queensland Law Society (QLS) members, the report of the survey focused on the nature and prevalence of discrimination and harassment in the Queensland legal workplace.

\footnotetext{
${ }^{*}$ Senior Lecturer, Faculty of Law, QUT.

${ }^{* *}$ Social researcher and postgraduate student, ANU.

${ }^{1}$ Queensland Law Society Equalising Opportunities in the Law Committee, 2003 Membership Survey: The Report (2006).
} 
This article discusses the background to the survey, including the record of women's lack of progress in the legal profession and the attempts made to assess whether any progress was being made after the introduction of discrimination legislation in Australia. The article sets out the methodology of, and basic statistics from, the survey. The results dealing with harassment and discrimination are analysed in terms of other Australian research, particularly that carried out by the Human Rights and Equal Opportunity Commission (HREOC). The article sets out the recommendations from the Report and examines some of the ways of responding to these recommendations. Efforts to amend the Law Council of Australia's Model Conduct Rules are ongoing. These rules are followed in Queensland's Professional Conduct Rules. Providing that these professional rules are changed, will the change be sufficient? What other changes need to be set in place to ensure that the legal workplace is more women-friendly?

\section{BACKGROUND}

The 2004 HREOC Report 20 Years On: The Challenges Continue ... Sexual Harassment in the Australian Workplace confirmed that the incidence of sexual harassment in Australia is 'broadly comparable with that of other like countries'. ${ }^{2}$ HREOC conducted a review of the sexual harassment in employment complaints from 2002. Following this they also organised a Gallup Organization telephone survey to extend the picture of sexual harassment in the workplace generally. This was Australia's 'first national survey of sexual harassment in the general community'. ${ }^{3}$ The report found that 'eighteen per cent of all respondents in the telephone survey had been harassed at work (28 per cent of women, seven per cent of men) ${ }^{4}$. The result of HREOC's research reinforces the many studies on work/life balance 5 and highlights the difficulties that women are facing in the modern workplace. According to Pru Goward, who echoes the general conclusion on the topic,

\footnotetext{
${ }^{2}$ Human Rights and Equal Opportunity Commission, 20 Years On: The Challenges Continue ... Sexual Harassment in the Australian Workplace (2004) 4.

http://www.humanrights.gov.au/sex_discrimination/workplace/challenge_continues/challenge continues.pdf at 8 June 2008.

${ }^{\overline{3}}$ Ibid.

${ }^{4}$ Ibid.

${ }^{5}$ See for example, Barbara Pocock Jobs, Care and Justice: A fair work regime for Australia Clare Burton Memorial Lecture Sydney 8 November 2006, http://www.barbarapocock.com.au/documents/Burton2006.pdf at 8 June 2008; and publications of the Centre for Work and Life http://www.unisa.edu.au/hawkeinstitute/cwl/default.asp at 8 June 2008.
} 
'[s]triking the balance' comes at 'a significant price' for both men and women. ${ }^{6}$

In the legal workplace, the high personal costs of legal practice are reflected in the revealing comments of one managing partner of a major law firm, who said: '[w]e expect our people to treat the client as if they were God and to put themselves out for clients. You don't say, "Sorry I can't do it, I'm playing cricket on the weekend"... You don't have a right to any free time'. ${ }^{7}$ Such expectations do not necessarily accord with the parenting responsibilities of either men or women.

Women face particular difficulties throughout Australian legal workplaces. This is an important issue for the profession. Findings from the present Queensland study echo those of many other studies that have taken place recently, including those of the Law Society of New South Wales. The findings are reflective of the community and issues identified in the Human Rights and Equal Opportunity Commission 2007 Final Report It's About Time: Women, Men, Work and Family. ${ }^{8}$ The HREOC final report raises many of the same issues addressed in the South Australian Premier's Council for Women Submission to the HREOC Inquiry. ${ }^{9}$ Research on work/life balance in the legal profession is also taking place in the United Kingdom..$^{10} \mathrm{~A}$ recent study there of 341 women solicitors highlights troubling issues of

lack of flexibility in the workplace, the long hours culture, the difficulty of fitting their work patterns into a male working paradigm, less favourable promotion prospects compared with male colleagues, poor management practices, and dehumanization of the individual by the firm. ${ }^{11}$

These are not simply 'Queensland' issues.

\footnotetext{
${ }^{6}$ Pru Goward, 'Work Life Balance' (Speech delivered at the Australian Institute of Management Breakfast, Sydney, 11 May 2006)

$<$ http://www.humanrights.gov.au/about/media/speeches/sex_discrim/worklife20060511.html> at 8 June 2008.

${ }^{7}$ T Featherstone (2005) 'It’s Just Not Cricket!', Business Review Weekly, 3 March 2005, 47.

${ }^{8}$ Human Rights and Equal Opportunity Commission, It's About Time: Women, Men, Work and Family - Final Paper 2007 (2007).

${ }^{9}$ South Australian Premier's Council for Women, Striking the Balance: Women, Men, Work and Family - Response to the Human Rights and Equal Opportunity Commission 2005

Discussion Paper (2005).

${ }^{10}$ Liz Duff and Lisa Webley, Equality and Diversity: Women Solicitors- Research Study 48 , Volume II Law Society Research Study Series (2004).

${ }^{11}$ Ibid 384.
} 


\section{A Women's Lack of Progress and Advancement}

Historically speaking, 2005 marked the centenary of the vote for women in Queensland and the centenary of the date on which the first woman, Grata Flos Greig, was admitted to practise law in Australia. ${ }^{12}$ Why is it that in the 100 years since then women have not progressed in the upper echelons of the legal profession relative to the numbers graduating from law schools? Why do women find the profession 'much less welcoming, accommodating and supportive than do their male peers', and consequently 'drop out' at a much higher rate than men ${ }^{13}$

The themes from the literature and reports from the last decade are familiar:

- Women generally comprise over 50 percent of law graduates;

- Women are not progressing through the hierarchies of the profession at a rate commensurate to their overall participation;

- Women are earning less than their male counterparts in the profession;

- Women tend to leave private practice in favour of the government and public sector and corporate employment;

- The costs of this attrition are substantial but not fully acknowledged; and

- Discrimination issues seem to be present. ${ }^{14}$

The consequences for the legal profession are dire if these issues are not addressed. The current situation is resulting in a 'waste of time and resources devoted to legal training', 'a lack of "vigour" and diversity in the profession', 'rigidity of structure in the management of collegiate relations', 'loss of talent', 'a lack of alternative models of service delivery', and a stagnant legal corporate culture generally. ${ }^{15}$

\footnotetext{
${ }^{12}$ Susan Purdon and Aladin Rahemtula (eds), A Woman's Place: 100 Years of Queensland Women Lawyers (2005) 11.

${ }^{13}$ Rosemary Hunter, 'Border Protection in Law's Empire: Feminist Explorations of Access to Justice' (2002) 11(2) Griffith Law Review 263, 279.

${ }^{14}$ The basis for this review of the literature can be found in Terry Hutchinson, 'Women in the Legal Profession in Australia: A Research Start' (2005) 13(2) Australian Law Librarian 23.

${ }^{15}$ New South Wales Department for Women, Gender Bias and the Law: Women Working in the Legal Profession - Report of the Implementation Committee (1996) 3; and see The Law Society of New South Wales, After Ada: A New Precedent for Women in Law (2002) 6. $<$ http://www.lawsociety.com.au/uploads/filelibrary/1036022928786_0.9151443275908748.pdf $>$ at 8 June 2008.
} 


\section{B Discrimination}

Federal and State anti-discrimination legislation provide some protection against the most common forms of discrimination - on the basis of gender, age, race, sexuality, disability and family responsibilities. In addition, the law prohibits other forms of objectionable behaviour, including sexual harassment and vilification or harassment on the basis of race, sexuality or disability. ${ }^{16}$ In particular, the Queensland Anti-Discrimination Act 1991 prohibits sexual harassment and vilification on the basis of race, sexuality and gender identity and the Commonwealth Disability Discrimination Act 1992 prohibits disability harassment. It should be noted here that the tenor of the Australian legislative framework tends to be based on positive acts of discrimination. There are other legislative frameworks. An example is to be seen in the United Kingdom where the Equality Act 2006 creates a duty on public authorities 'to promote gender equality of opportunity between women and men ('the gender duty'), and to prohibit sex discrimination in the exercise of public functions' ${ }^{17}$ Under the UK legislation, a new Commission for Equality and Human Rights (CEHR) has taken on the work of the existing equality commission and also has the responsibility for promoting human rights more generally. Some commentators have considered that the Act will mean that 'public authorities, and private deliverers of public functions, will have a duty to promote gender equality'. ${ }^{18}$ Reference has been made to the necessity for firms to have gender, diversity and equality policies in place prior to anyone from their organisations being considered for judicial appointment, for example. ${ }^{19}$

The 1994 Australian Law Reform Commission's report Equality before the Law: Women's Equality ${ }^{20}$ recommended that more education be carried out regarding the Sex Discrimination Act 1984 (Cth) and the obligations of law firms under this Act. These recommendations have continued to be highly publicised. ${ }^{21}$ The ALRC Report was supportive of model equal employment

\footnotetext{
${ }^{16}$ Anti-Discrimination Act 1991 (Qld); Age Discrimination Act 2004 (Cth); Disability Discrimination Act 1992 (Cth); Human Rights and Equal Opportunity Commission Act 1986 (Cth); Racial Discrimination Act 1975 (Cth); Sex Discrimination Act 1984 (Cth).

${ }^{17}$ Explanatory Notes, Equality Bill 2005 (House of Commons) [4].

${ }^{18}$ Rachel Rothwell, 'Equality Bill to Rock Firms' (2006) Law Society Gazette.

${ }^{19}$ Ibid.

${ }^{20}$ Australian Law Reform Commission, Equality before the Law: Women's Equality, Report No 69 Part 2 (1994).

${ }^{21}$ Human Rights and Equal Opportunity Commission, Good Practice, Good Business: Eliminating Discrimination and Harassment in the Workplace (2008) Human Rights and Equal Opportunity Commission: Information for Employers

$<$ http://www.humanrights.gov.au/info_for_employers/index.html $>$ at 29 February 2008.
} 
policies. However, in 2003 Dobinson commented that, despite measures taken to address the inquiry's findings, men still continue to dominate legal services, 'especially in the upper reaches of the profession and the judiciary'. ${ }^{22}$

The topic has not lacked research. In 1994, the NSW Department for Women (then Ministry for the Status and Advancement of Women) commenced a comprehensive research program on gender bias in the legal system. ${ }^{23}$ As part of this program, the Ministry commissioned the Keys Young Report, Gender Bias and the Law - Women Working in the Legal Profession in NSW. ${ }^{24}$ Anecdotal evidence had suggested that women lawyers were discriminated against in their practice of law on the basis of their sex. ${ }^{25}$ The Report found

considerable evidence that women's current status in the profession is not explicable purely in terms of historical factors, nor by virtue of women's choices and preferences. There is evidence that women lawyers have been denied opportunities to advance, to earn the same amount of money as their male colleagues or to remain and progress within their chosen place of employment. $^{26}$

Surveys were conducted to determine the "nature, extent and causes of job satisfaction and dissatisfaction among solicitors and to identify any gender specific issues and problems'. ${ }^{27}$ The results demonstrated that

[a]mong professional employees, job satisfaction is principally determined by the extent to which their human needs are met. At many law firms, the corporate environment and practices in human resources management are adverse to job satisfaction because they do not adequately provide for the human needs of employees. ${ }^{28}$

The Report adds that 'women, more concerned with maintaining balanced lives, will not pursue success at any cost and are less likely to tolerate these conditions'. ${ }^{29}$ It concludes therefore that 'the resulting differences in

\footnotetext{
${ }^{22}$ Jonathan Dobinson, 'Equality before the Law (ALRC 67 and 69)' (2003) 83 Reform 37.

${ }^{23}$ New South Wales Department for Women, above n 15.

${ }^{24}$ Keys Young, Gender Bias and the Law: Women Working in the Legal Profession in NSWSummary Report, March 1995 (1995).

${ }^{25}$ New South Wales Department for Women, above n 15, 7.

${ }^{26}$ Ibid ii.

${ }^{27}$ Mark Herron, Annie Woodger and George Beaton, Facing the Future: Gender, Employment and Best Practice Issues for Law Firms: Final Report (1996) vii.

${ }^{28}$ Ibid. xii.

${ }^{29}$ Ibid.
} 
experience of the workplace are open to the interpretation of discrimination'. 30

Some discussion of these issues also took place in Tasmania in $1996{ }^{31} \mathrm{~A}$ Women Lawyers Association Report found that

[t]here is clear evidence of a disparity between graduation rates and the levels of seniority achieved by women in private practice. Compared with rates of graduation over time, women are under-represented among practising lawyers. This suggests a high attrition rate for women compared with men. ${ }^{32}$

The report also found that '[w]omen are seriously under-represented at principal level in private practice, even taking into account historically low rates of entry into the profession by women and the necessary time lag between graduation and the achievement of principal level'. ${ }^{3}$ The data obtained from the survey of women lawyers indicated that gender bias inhibits the career advancement of women in the legal profession. It was reported by 58 percent of questionnaire respondents that gender had a negative impact on their career progression, and another 75 percent of respondents with children said that pregnancy/children had a negative influence on their career progression. The report found that 'career interruptions' were a 'major barrier' to advancements to principal level. ${ }^{34}$ There was also 'alarming evidence of sexual harassment'. ${ }^{35}$ Overall, it would seem that 'the key reason for the discrepancy is that the prevailing culture and work practices in the legal profession in Tasmania fail to accommodate the needs of women with family responsibilities'. ${ }^{36}$ There were reports of:

- 'systemic discrimination, that is, work practices which prevent women with children from working in senior positions in the profession';

- 'a constraining of women's own choices which prevent them from aspiring to senior levels in the professions'; and

\footnotetext{
${ }^{30}$ Ibid xii.

${ }^{31}$ Jane Goodluck, 'Women Working in the Legal Profession in Tasmania: Final Report' (Prepared for the Women Lawyers Association of Tasmania, Ireland and Goodluck Corporate Consultants, 1996). See also Tasmanian Women's Consultative Council, Women and Justice:

Tasmanian Women's Access to the Legal System (1995).

${ }^{32}$ Goodluck, above n $31,1$.

${ }^{33}$ Ibid.

${ }^{34}$ Ibid 2 .

${ }^{35}$ Ibid.

${ }^{36}$ Ibid.
} 
- 'active discrimination against women on the grounds that they are likely to be less 'permanent' employees as a result of their traditional care giving role'.

In 2001, the Law Council of Australia's 2010 Project $^{38}$ noted several key studies and commented that they showed similar results, that is:

Women are over represented in the lower echelons of the profession and under-represented in the upper echelons. Women leave the profession in disproportionate numbers. They do so for various reasons, but these cannot be attributed solely or predominantly to family responsibilities. The assumption that, given time, the number of women entering at the bottom of the profession would be reflected in senior ranks has not materialised. ${ }^{39}$

The report discusses the reasons for the lack of women's progress and concludes that they 'seem to relate primarily to family responsibilities'. Motherhood is named as an impediment to advancement. This issue of work/life balance is reflected in the main challenges identified in the paper. These are directed primarily to the firms and the professional bodies. The following were identified as challenges for firms:

- Developing human resources policies reflecting an appropriate worklife balance for staff at all stages of their careers, issues including expanded leave categories, flexible part time work policies and telecommuting;

- Developing a range of alternative career paths;

- Ensuring partners have appropriate leadership and mentoring skills; and

- Ensuring all staff have career development opportunities, access to training opportunities and variety of work. ${ }^{41}$

These reports are now dated but the recent Queensland survey underscores the importance of the issue for women and the need for workplace change.

Accurate statistics are difficult to access. The Law Council's 2010: A Discussion Paper - Challenges for the Legal Profession commented that

\footnotetext{
${ }^{37}$ Ibid.

${ }^{38}$ Law Council of Australia, 2010: A Discussion Paper-Challenges for the Legal Profession (2001).

${ }^{39}$ Ibid 132.

${ }^{40}$ Ibid 133.

${ }^{41}$ Ibid xii.
} 
'there are no definitive statistics on the legal profession in Australia' ${ }^{42}$ The UK Law Society has researched the area much more thoroughly. ${ }^{43}$ The most reliable Australian statistics appear to be those from the New South Wales Law Society Keys Young analysis of data from their annual Practising Certificate Surveys. Kim Cull, the then President of the Law Society of NSW commented in 2002 on the 2001 Survey:

It's very difficult to see why there is such a low number of women attaining partnership. Over the last 10 years there's been an increase of about 193 percent of women entering the profession and in the same period the number of women attaining partnership has only increased between 8 and 15 percent. $^{44}$

Interestingly, part of the reason may be that males are strongly represented in private practice, while relatively more females work as government or corporate solicitors. The objective of the QLS survey, therefore, was to provide some accurate statistics for the practising profession in Queensland.

\section{METHODOLOGY}

The Queensland Law Society Equalising Opportunities in the Law Committee included pertinent questions on discrimination within the Annual Practising Certificate Survey. This Survey was distributed to all Queensland Law Society members with their renewal forms in 2003. Approximately 6401 survey forms were distributed. There were 2536 respondents. This represents a response rate of 41.5 percent.

The survey form consisted of 19 questions and most questions gave an option for the respondent to add further comments or elaboration. There were a number of respondents who included comments. These have been documented, categorised and analysed. They provide a qualitative aspect to the study. These comments will also be an important guide in the redesigning of the survey form for future studies. There were a number of missing values on the survey. For example, 233 respondents did not report their salary. Missing values were excluded from the analysis.

\footnotetext{
${ }^{42}$ Ibid vii.

${ }^{43}$ See The Law Society, Women Solicitors (2006) Law Society Fact Sheet Series $<$ http://www.lawsociety.org.uk/aboutlawsociety/whatwedo/researchandtrends/factsheets.law $>$; The Law Society of Scotland and Equal Opportunities Commission Scotland, Women in the Legal Profession in Scotland (2005).

${ }^{44}$ Clare Buttner, 'Unequal Before the Law - Insight', Sydney Morning Herald (Sydney), 24 June 2002, 9.
} 
The survey incorporated two main parts. First, basic descriptive questions were asked regarding factors such as age, gender, minority identification, years in practice, employment role, salary, hours of work, location and size of practice, engagement in pro bono work or other employment, and the subject area of their practice. Other questions focused on job satisfaction and career prospects, any time out of practice and the reason for this time away. The relationship between these factors was examined in order to provide a picture of the respondent group. It was possible, for example, to compare the gender composition of each of the age groups.

Secondly, the study analysis sought to identify the perceptions of discrimination within the legal community. Question 14 of the Survey asked: 'Have you ever experienced harassment / discrimination during your legal career based on any of the following factors?' The categories of discrimination identified were gender, age, race, family responsibilities, sexual preferences, pregnancy, disability, religion, marital status, and 'other'.

Comparing responses to section 2 against the variables in section 1, the data reveals certain groups who show a significantly higher rate of discrimination compared to the rest of the population. For example, those in practice 6-9 years were over represented within the group reporting discrimination by gender.

\section{FINDINGS}

\section{A Some Basic Statistics}

Of the 2536 members who completed the survey, 34.2 percent of respondents were female. This gender profile is representative of the practising profession in Queensland which consisted of 33.8 percent women and 66.2 percent men at the time of the survey in $2003 .^{45}$

Women predominated in the younger brackets of the profession, representing 62 percent of those under 29 years of age. The Annual Report for the Queensland Law Society for 2001-2002 shows an overall 10 year increase of 47.8 percent in the number of Practising Certificates issued, and a 10 year increase of 79.5 percent in the number of admissions. ${ }^{46}$ It is likely that a great number of these younger practitioners coming into the profession were female but the Annual Report statistics do not provide an age by gender

\footnotetext{
${ }^{45}$ Queensland Law Society, 75th Annual Report 2002-2003 (2003).

${ }^{46}$ Queensland Law Society, 74th Annual Report 2001-2002 (2002), 17.
} 
breakdown. According to this survey result, the proportion of women in the workforce decreased steadily after age 30 . Men represented almost threequarters of those aged 40-49 years, and a massive nine out of ten respondents over the age of 50 were males. These demographics were possibly reflected in the salaries, with male practitioners earning considerably more than their female counterparts.

A large 41 percent $(n=1015)$ of respondents were working between 40 and 49 hours with a further 44 percent $(n=1091)$ working over 50 hours per week. Despite this, job satisfaction was reasonably high with over 77 percent $(n=1904)$ reporting that they were satisfied or very satisfied with their current jobs.

There was little diversity within the Queensland profession. Only 4.8 percent of respondents identified themselves as having English as a second language, 1.3 percent as having a disability, and a mere 0.2 percent identified themselves as Indigenous.

\section{B Unequal Pay}

Overall salaries in the Australian legal profession are reported to have improved recently. A range of factors currently underpin lawyers' decisions on how and when they work, and money is just one of them. Mahlab Recruitment's annual legal salary survey, released on 2 August 2007, indicates that salary bands for Australian lawyers increased by approximately five percent across the nation over the past year. The salaries of Perth-based lawyers rose by nine percent, while Sydney lawyers received an average 6.4 percent pay rise during the year and the pay of Melbourne lawyers rose by 5.3 percent. However, up to 58 percent of lawyers nationally claimed they were considering leaving their current firms. Remuneration and work/life balance were found to be the most important factors underpinning those deliberations. ${ }^{47}$ According to the 2002 New South Wales Report,

[w]hen women are partners their earnings are on par with those of men. However as solicitors, women still earn on average less than men. Last year women's salaries were on average $76 \%$ of men's salaries. This year that ratio has improved, with women now earning $82 \%$ of the salaries that men earn. For solicitors who have been admitted for less than one year there was a gap of $\$ 8,200$ in favour of male solicitors. ${ }^{48}$

\footnotetext{
${ }^{47}$ Marsha Jacobs, 'Lifestyle a Big Issue for Lawyers', Australian Financial Review (Sydney), 3 August 2007, 59.

${ }^{48}$ The Law Society of New South Wales, above n 15, 6 .
} 
The Law Institute of Victoria also undertakes an Annual Survey of Legal Practitioners. The 1999 published results report that 'female earnings were, on average, significantly lower than male earnings' ${ }^{49}$ The 2004 Law Society of New South Wales Annual Statistics show that 'female solicitors now make up $40 \%$ of the practising profession. In the year ending 1 October 2004, of those entering the profession for the first time, $57.9 \%$ were women and $42.1 \%$ were male ${ }^{50}$ The Report notes that

as in past years, male respondents reported earning higher incomes than females. For example, $39.7 \%$ of all men, but only $19.4 \%$ of women, reported incomes over $\$ 100,000$; while $31.2 \%$ of women, compared to only $18.8 \%$ of men, reported earning less than $\$ 50,000$. The approximate mean income reported by male practitioners was $\$ 94,400$, while for female practitioners it was $\$ 73,100 .^{51}$

The research that has taken place in the United Kingdom demonstrates a similar trend. ${ }^{52}$

The results of the present study bear out these figures. Male practitioners were definitely earning more than their female counterparts. This was especially so in the over $\$ 100,000$ category where 39 percent of men but only 12 percent of women were earning over this figure. This might in some way be explained by the fact that 89 percent of those who had been in practice for over 20 years were male. There was a marked and statistically significant difference between the earnings scores of males and females across the firm structure. For equity partners, 43 percent of men earned over $\$ 200,000$ as opposed to only 28 percent of women. For salaried partners, 71 percent of men earned over $\$ 100,000$ as opposed to only 42 percent of women. For associates, 24 percent of men earned over $\$ 100,000$ in contrast to only 11 percent of women. For employed solicitors, 57 percent of men earned over $\$ 50,000$ whilst only 41 percent of women earned this amount. Clearly, the discrepancy between gender earnings continues to be a significant problem in the Queensland legal profession.

\footnotetext{
${ }^{49}$ Roy Kriegler, 'LIV Annual Survey of Legal Practitioners' (1999) 73(3) Law Institute of Victoria 52, 5.

${ }^{50}$ JHD Urbis, '2004 Profile of the Solicitors in New South Wales' (Prepared for The Law Society of New South Wales, 2005) 14.

${ }^{51}$ Ibid 33.

${ }^{52}$ Department for Constitutional Affairs (UK), Increasing Diversity in the Legal Profession: A Report on Government Proposals (2005) 28; The Law Society of Scotland and Equal Opportunities Commission Scotland, above n 43.
} 


\section{Figure 1: Earnings Reported by QLS Respondents}

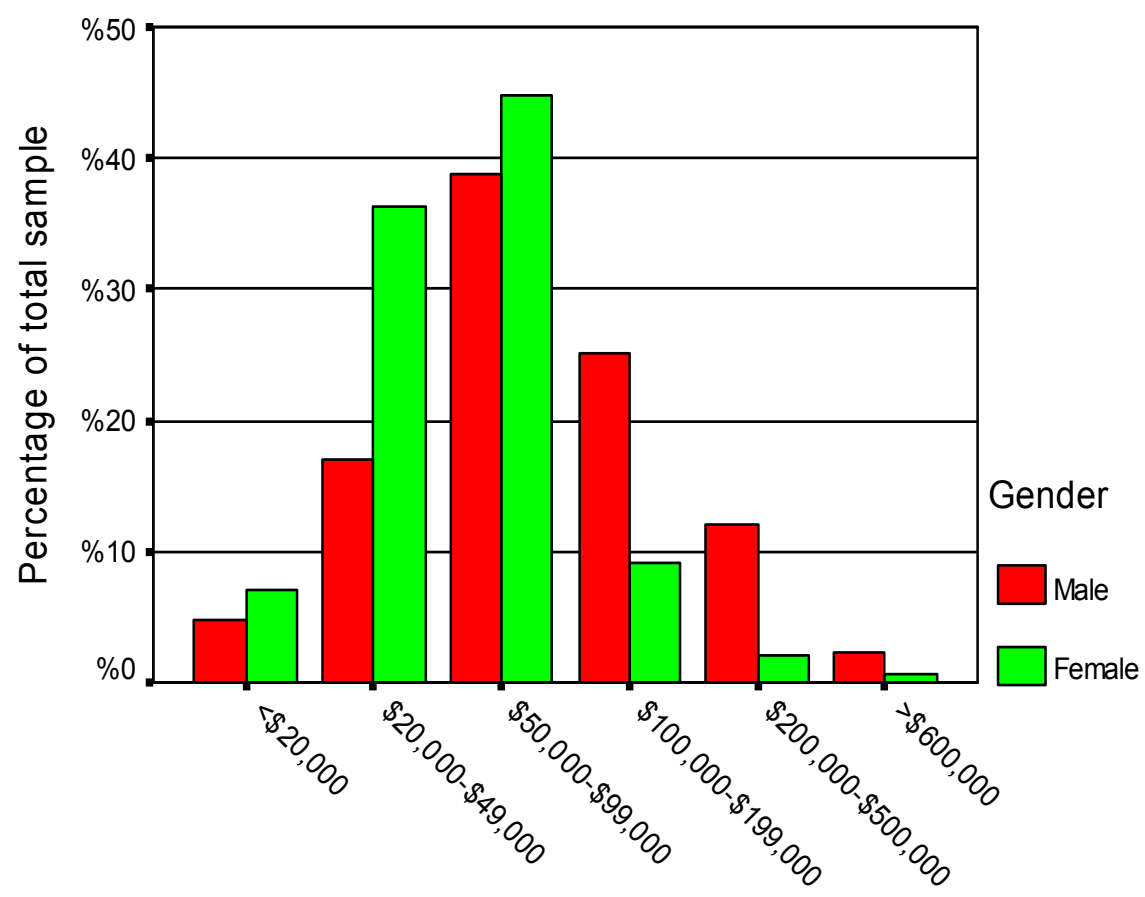

Pre-tax earnings FY2001-02

\section{Harassment and Discrimination}

Survey results reveal 595 total reports of workplace discrimination, as reported by 381 individuals. This means that 15 percent of the 2536 practitioners who responded to the survey had experienced some form of discrimination during their legal career, with 8 percent of respondents reporting more than one type of discrimination. Over 5 percent of respondents also reported that they knew of other people suffering discrimination in the workplace.

The types of discrimination reported included gender $(8.2 \%)$, age $(3.5 \%)$, family responsibilities $(3.3 \%)$, pregnancy $(1.7 \%)$, marital status $(1.3 \%)$, race $(1.1 \%)$, sexual preferences $(0.7 \%)$, religion $(0.7 \%)$, disability $(0.4 \%)$, and 'other' instances not included in these categories (2.5\%). Overall, more than twice as many women as men indicated that they had experienced discrimination in one or more forms. Taken as a percentage of the gender cohort, 30 percent of women reported having experienced discrimination 
whilst only 7 percent of men reported the same. The figure below illustrates this difference.

\section{Figure 2: Discrimination Reported by QLS Respondents}

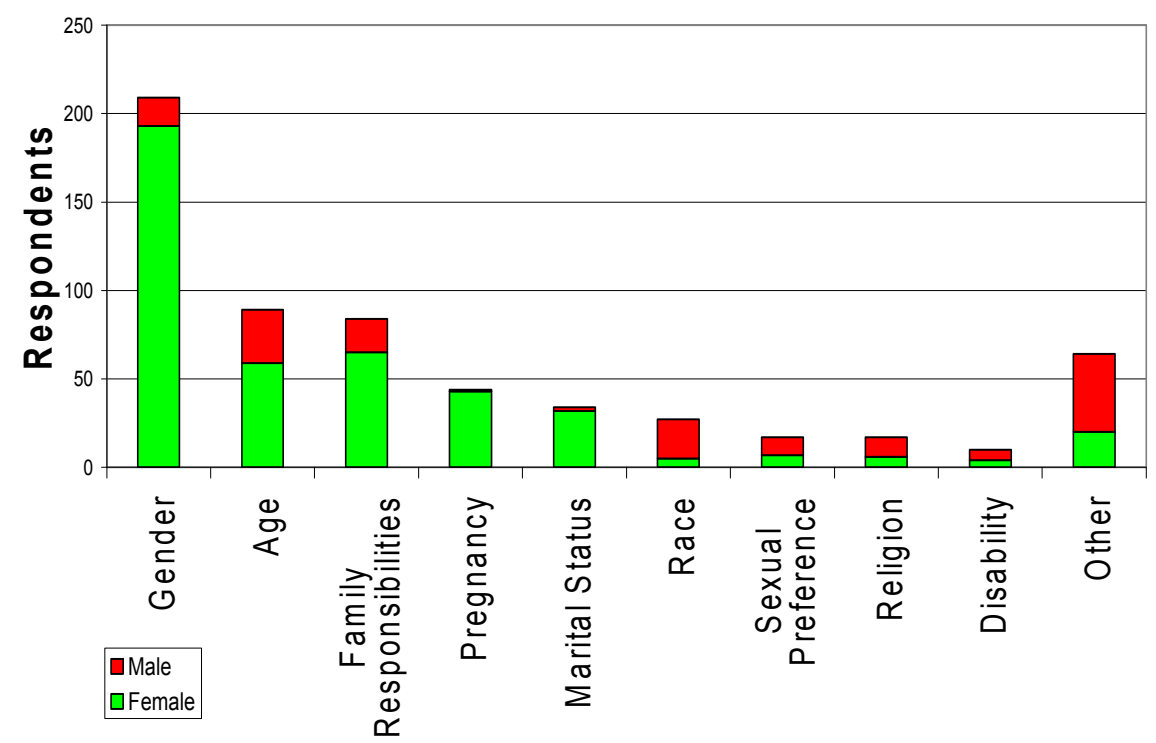

Nature of Discrimination

\section{Discrimination on the Basis of Gender}

Of the respondents, 8 percent $(n=209)$ reported having experienced discrimination on the basis of gender. Not surprisingly, 92 percent of those experiencing gender discrimination were female. Younger people were also more likely to report discrimination of this type, with those in the 25-29 year age group being twice as likely to experience gender discrimination. In contrast, the over 50 age group did not report a high incidence of discrimination by gender. In that age group 89 percent were male.

Further odds ratio analysis shows that certain groups of women were more likely to report experiencing discrimination because of their gender. These respondents were predominantly younger female employed solicitors or associates. Not surprisingly, this group viewed their prospects pessimistically and had high dissatisfaction levels. 


\section{Discrimination on the Basis of Age}

There were 89 respondents who reported having experienced discrimination on the basis of age, representing 3.5 percent of the survey population. Again, gender was a key factor in this form of discrimination, with women being four times more likely than men to report having experienced discrimination on the basis of age. Those women who experienced age discrimination were three and a half times more likely to be aged over 50 and two and a half times more likely to work in a small firm with fewer than 3 partners. Males represented 66 percent of all respondents, yet of those reporting discrimination by age, only 34 percent were male.

Persons reporting discrimination on the basis of age were more than twice as likely to come from the $25-29$ year old age group (odds ratio=2.21), and 83 percent $(n=25 / 30)$ were female. The other age group found more likely to experience age discrimination was those over the age of 50. Reports of age discrimination were over twice as likely to come from respondents who had practised $0-5$ years or received a salary of $\$ 20,000-\$ 50,000$. Discrimination by age did not appear to affect the satisfaction rating with respondents' work and positions. This contrasts with the effect of gender discrimination, which led to significant findings of dissatisfaction.

\section{Discrimination on the Basis of Family Responsibilities}

There were 3.3 percent of respondents who reported discrimination on the basis of family responsibilities $(\mathrm{n}=84)$. Women made up over three quarters of this group.

Of those respondents reporting discrimination on the basis of family responsibilities, 23 percent came from the 35-39 year old age group whilst people of this age made up only 12 percent of the population of respondents. Similarly, 37 percent of respondents reporting this discrimination came from the 40-49 year old age group whilst only 27 percent of all respondents were in this age group. The most striking statistic in this area was for those who had been in practice for 10-19 years. This group made up 46 percent $(n=39 / 84)$ of all those who reported discrimination on the basis of family responsibilities. Yet across all respondents, this practice group represented only 27 percent $(n=678)$ of the survey population. Using odds ratio analysis we see that persons experiencing this form of discrimination were twice as likely to be associates in the firm (odds ratio $=2.04$ ). 
Conversely, of those reporting discrimination on the basis of family responsibilities 18 percent $(n=15 / 84)$ had been in practice for $0-5$ years, whilst this practice group made up 28 percent of the survey population $(\mathrm{n}=718)$. According to odds ratio analysis, those in the $0-5$ year practice group were half as likely to experience discrimination on the basis of family responsibilities (odds ratio $=0.54$ ). Common sense would suggest that this group consists of younger practitioners who are less likely to have children or family constraints on their time. Others who were less likely to report discrimination on the basis of family responsibilities are those practising in rural Queensland areas (odds ratio $=0.71$ ). Again, one may hypothesise that practitioners in these areas find it somehow easier to manage a work/life balance. Those reporting discrimination on the basis of family responsibilities were generally more dissatisfied with their workplace experience.

\section{Discrimination on the Basis of Pregnancy}

Forty-four respondents (1.7 percent) reported discrimination on the basis of pregnancy, and of those the women were three times more likely to be aged $40-49$ years old (odds ratio $=3.33$ ). Of those reporting discrimination on the basis of pregnancy, 46 percent $(n=20 / 44)$ were in the $10-19$ years practice group whilst this group made up only 27 percent $(n=678)$ of the survey population. Out of those who reported discrimination on the basis of pregnancy, only 2 percent $(n=1 / 44)$ were equity partners. Also, out of the 85 salaried partners none reported discrimination on the basis of pregnancy. Persons discriminated against on the basis of pregnancy were over two and a half times more likely to be associates or consultants. Persons discriminated against on the basis of pregnancy were three times more likely than other respondents to be dissatisfied with their employment (odds ratio=3.10).

The most recent Australian Bureau of Statistics report Pregnancy \& Employment Transitions Survey, released on 23 October 2006, found that 'at least one difficulty was reported by $22 \%$ of women' who worked for an employer while pregnant, with the most common forms being 'receiving inappropriate or negative comments', 'missing out on training or development opportunities', and 'missing out on opportunities for promotion' ${ }^{53}$ The results in this 2003 survey study are therefore consistent with national trends.

\footnotetext{
${ }^{53}$ Australian Bureau of Statistics, 4913.0 - Pregnancy and Employment Transitions, Australia, Nov 2005 (2006).
} 


\section{Discrimination on the Basis of Marital Status}

Women predominated in the group reporting discrimination on the basis of marital status, representing 94 percent of those reporting this discrimination. Of this group, 35 percent were aged 25-29 years old and/or had been in practice less than five years.

Of those reporting discrimination on the basis of marital status, 59 percent $(n=20 / 34)$ worked in the Brisbane CBD and 35 percent $(n=12 / 34)$ were employed solicitors. These represent higher rates than that of the survey population, being 45 percent and 28 percent respectively. Persons discriminated against on the basis of marital status were nearly twice as likely to come from the 10-19 years practice group, and were over two-and-a-half times more likely to be dissatisfied with their employment.

\section{$6 \quad$ Reporting Discrimination}

Of the 381 respondents who indicated that they had experienced discrimination, only 18 lodged any type of formal complaint. Those who did not lodge a complaint were asked why they chose not to act. Many of these responses were very concerning, with many saying that complaining 'would have had negative repercussions' and that 'it's not worth it' or it 'won't change'. Some resigned from their position or 'ignored it', deciding that it was a 'minor issue' that was 'not serious enough' to pursue. A few individuals took their own actions to resolve the situation, or used their harassment as a bargaining position, yet for the most part those discriminated against seemed to feel that there was 'no point' in pursuing the complaints process. As one individual tellingly responded: 'Would you?' This sense of disempowerment is particularly concerning.

These reporting rates are much lower than those indicated by the HREOC survey which found that 'less than one third of interviewees to the telephone survey who experienced sexual harassment in the workplace stated that they made a formal report or complaint about the sexual harassment ${ }^{54}$ However, even according to the HREOC survey, only one percent made a complaint to HREOC or a State or territory anti-discrimination agency. Most reported only to their manager or employer. The reasons for not reporting the sexual harassment predominantly fell into three categories:

- 'a lack of faith in the formal complaints mechanism';

\footnotetext{
${ }^{54}$ Human Rights and Equal Opportunity Commission, above n 2, 10.
} 
- 'a belief that the experience was not serious enough to warrant reporting'; and

- 'the target dealing with the problem themselves'. ${ }^{55}$

In the QLS study, of the 18 individuals who did report their discrimination, the majority took the issue up with a partner or manager in their firm. Only a handful (6) of those experiencing discrimination lodged a complaint with an authority such as the police, courts, Law Care, HREOC, or the Industrial Relations Commission. Interestingly, those who did complain were more likely to have experienced discrimination on the basis of disability, race, or sexual preference. One may wonder whether these forms of discrimination have received more public attention in recent times, thus increasing the individual's sense that such discrimination can be successfully fought.

\section{$7 \quad$ Comparison with HREOC Findings}

The HREOC Report findings on sexual harassment in the workplace demonstrated that ' $18 \%$ have personally experienced sexual harassment in the workplace at some time' and 11 percent had experienced sexual harassment in the last five years. ${ }^{56}$ The QLS Survey was phrased to include both harassment and discrimination based on a number of stated characteristics. It did not define either term. The QLS percentage on gender discrimination may initially appear lower than the HREOC findings. However, a QLS respondent wishing to report sexual harassment could have included this under one of several categories, including gender (8.2\%), family responsibilities $(3.3 \%)$, pregnancy $(1.7 \%)$, marital status $(1.3 \%)$, and sexual preferences $(0.7 \%)$, so perhaps the difference between the two research findings is not so marked. The overall QLS figure was approximately 15 percent, being only 3 percent lower than the HREOC figure. Furthermore, it is important to note that the HREOC research was carried out by a totally independent body and not a professional organisation as was the case with the Law Society study. Whilst the methodology of the QLS survey ensured respondent anonymity, there may have been an element of non-reporting motivated by a suspicion that the information might in some way become detrimental to the employee's position. This methodological hurdle was unavoidable for the QLS survey, and may have hampered full disclosure by respondents. Alternatively, perhaps the QLS percentage is simply lower than the national average, in which case this would be positive and welcome news and should be acknowledged as such.

\footnotetext{
${ }^{55}$ Human Rights and Equal Opportunity Commission, above n 2, 7.

${ }^{56}$ Ibid 8.
} 


\section{Responses to the IsSUES RaISED IN THE REPORT}

The challenges highlighted for the profession from the QLS basic survey are fairly clear and echo themes identified in the HREOC and other reports. The Law Council of Australia has been seeking to advance solutions to these issues through its various committees, such as the Equalising Opportunities in the Law Committee, which include representatives from the State law societies and other concerned associations such as the Women Lawyers Association. The Queensland study made the following six recommendations: ${ }^{57}$

1. The Society needs more and better statistics on the profession including the costs of attrition, so as to encourage firms to review their recruitment practices and their work condition policies. The progress of women in the legal profession should be monitored and reported to encourage change. Perhaps this can be accomplished by another follow-up survey of the Queensland profession in order to map the effectiveness of any changes occurring. The Society should encourage a national study possibly in conjunction with the Law Council of Australia;

2. The Society needs to include sex discrimination, bullying and sex harassment provisions in the rules of professional conduct;

3. The Society needs to include equal opportunity affirmative actions and sex harassment issues in training courses and mandatory continuing legal education programs, as well as education on equity issues for members;

4. While there is legislation in place that can be used to enforce rights, the profession seems reluctant to use these avenues. ${ }^{58}$ More appropriate ways of handling grievances should be investigated;

5. The Society should be encouraging and assisting employers to address the barriers to the career advancement of women lawyers and

\footnotetext{
${ }^{57}$ Queensland Law Society Equalising Opportunities in the Law Committee, above n 1, 46-47.

${ }^{58}$ New South Wales Department for Women, above n 15. Prior studies had shown that women were not using these formal legislative avenues.
} 
lawyers from the various equity groups. Guidelines should be developed to promote equal employment opportunity in law firms; ${ }^{.59}$

6. The Society needs to develop some minimum standards or benchmarks for employment related issues such as billable hours of work and telecommuting. We should develop and implement changes to work practices to accommodate the family responsibilities of both men and women lawyers. ${ }^{60}$ There should be an attempt made to develop 'best practice' guidelines for enterprise agreements in law firms. ${ }^{61}$

These recommendations were not new. Similar points and proposals had been made in many of the earlier reports on women working in the legal profession.

\section{A Looking More Closely at the Rules of Professional Misconduct}

While progress is taking place on these recommendations, some aspects require further elaboration here. In particular, since the Survey was conducted, the Legal Profession Act 2004 (Qld) came into force. This resulted in reforms to the complaint handling procedures against legal practitioners, and the establishment of the office of the Legal Services Commissioner. Following this, the celebrated case of Baker v Legal Services Commissioner [2006] 2 Qd R 249 endorsed the principle that 'the use of insulting and offensive language to clients and employees is not acceptable behaviour by a solicitor'. ${ }^{62}$ Charges arose out of the practitioner's use of offensive language to or in the presence of a client and of members of the firm's staff. Other charges related, for example, to dishonestly charging professional fees where none were chargeable and failing to adequately supervise employed solicitors. Because the charges against Mr Baker related to behaviour that had occurred prior to the introduction of the Act, the charges were determined by reference to the meaning of "professional

\footnotetext{
59 This recommendation is in accord with suggestions for action in the New South Wales Department for Women, Response to Gender Bias and the Law: Women Working in the Legal Profession in New South Wales, October 1995 (1995).

60 This recommendation echoes a recommendation from Goodluck, above n 31, 3 .

${ }^{61}$ A similar recommendation was contained in New South Wales Department for Women, above n 59 .

${ }^{62}$ Ian Foote, Darielle Campbell and Michael Roessler, 'Solicitors' Professional Responsibilities to their Clients: The Michael Baker Disciplinary Decision' (2006) 26(5) PROCTOR, 43, 46. See Baker v Legal Services Commissioner [2006] 2 Qd R 249, [213].
} 
misconduct' and 'unprofessional conduct or practice' within the meaning of the Queensland Law Society Act 1952 (Qld). However, it would seem that the 2004 legislation widened the scope of practitioner duties in respect to the standards of 'unsatisfactory professional conduct' and 'professional misconduct'. The relevant 2004 provisions are outlined in Figure 3.

\section{Figure 3: Legal Profession Act 2004}

\section{Meaning of unsatisfactory professional conduct}

Unsatisfactory professional conduct includes conduct of an Australian legal practitioner happening in connection with the practice of law that falls short of the standard of competence and diligence that a member of the public is entitled to expect of a reasonably competent Australian legal practitioner.

\section{Meaning of professional misconduct}

(1) Professional misconduct includes-

\section{Meaning of professional misconduct}

(1) Professional misconduct includes-

(a) unsatisfactory professional conduct of an Australian legal practitioner, if the conduct involves a substantial or consistent failure to reach or maintain a reasonable standard of competence and diligence; and

(b) conduct of an Australian legal practitioner, whether happening in connection with the practice of law or happening otherwise than in connection with the practice of law that would, if established, justify a finding that the practitioner is not a fit and proper person to engage in legal practice.

(2) For finding that an Australian legal practitioner is not a fit and proper person to engage in legal practice as mentioned in subsection (1), regard may be had to the suitability matters that would be considered if the practitioner were an applicant for admission or for the grant or renewal of a local practising certificate.

The corresponding provisions in the new Legal Profession Act 2007 (Q1d) are substantially the same. New sections 418 and 419 are the same as the old sections 244 and 245 . Section 420 is in slightly wider terms than the previous s 246 .

\section{Figure 4: Legal Profession Act 2007}

420 Conduct capable of constituting unsatisfactory professional conduct or professional misconduct

The following conduct is capable of constituting unsatisfactory professional 
conduct or professional misconduct-

(a) conduct consisting of a contravention of a relevant law, whether the conduct happened before or after the commencement of this section; Note-

(1) Under the Acts Interpretation Act 1954, section 7, and the Statutory Instruments Act 1992, section 7, a contravention in relation to this Act would include a contravention of a regulation or legal profession rules and a contravention in relation to a previous Act would include a contravention of a legal profession rule under the Legal Profession Act 2004.

(b) charging of excessive legal costs in connection with the practice of law;

(c) conduct for which there is a conviction for-

(i) a serious offence; or

(ii) a tax offence; or

(iii) an offence involving dishonesty;

(d) conduct of an Australian legal practitioner as or in becoming an insolvent under administration;

(e) conduct of an Australian legal practitioner in becoming disqualified from managing or being involved in the management of any corporation under the Corporations Act;

(f) conduct of an Australian legal practitioner in failing to comply with an order of a disciplinary body made under this Act or an order of a corresponding disciplinary body made under a corresponding law, including a failure to pay wholly or partly a fine imposed under this Act or a corresponding law;

(g) conduct of an Australian legal practitioner in failing to comply with a compensation order made under this Act or a corresponding law.

(2) Also, conduct that happened before the commencement of this subsection that, at the time it happened, consisted of a contravention of a relevant law or a corresponding law is capable of constituting unsatisfactory professional conduct or professional misconduct.

(3) This section does not limit section 418 or 419.

Under the previous legislative arrangements, the Queensland Solicitors' Handbook (section 18.02) spelled out the situation more specifically:

A legal practitioner has an ethical obligation to recognise the essential dignity of each individual in a democratic society and the principles of equal rights and justice. This applies to all legal practitioners in relationships with all people. The Queensland Law Society condemns all forms of harassment, discrimination and other conduct against any person prohibited by any state or federal law. ${ }^{63}$

${ }^{63}$ Queensland Law Society, Solicitors' Handbook (2003) 77. 
Specific provisions dealing with unlawful discrimination, sexual harassment and workplace bullying were not included in the Legal Profession (Solicitors) Rules 2007 (Qld) on the basis that they had not been included in the Law Council of Australia's National Model Rules of Professional Conduct and Practice. Thus the provisions in the Solicitors' Handbook were superseded upon the adoption of the Model Rules. Not all States have adopted this uniformity of approach and the New South Wales, South Australian and Western Australian Regulations do include relevant rules.

Figure 5: Professional Conduct Rule Provisions across Australia ${ }^{64}$

\begin{tabular}{|c|c|c|}
\hline State & Source & Provision \\
\hline NSW & $\begin{array}{l}\text { Legal Profession } \\
\text { Regulations } 2005\end{array}$ & $\begin{array}{l}175 \text { Discriminatory conduct (including sexual } \\
\text { harassment) prohibited } \\
\text { Conduct, whether consisting of an act or omission, } \\
\text { that constitutes unlawful discrimination (including } \\
\text { unlawful sexual harassment) under the Anti- } \\
\text { Discrimination Act } 1977 \text { against any person must not } \\
\text { be engaged in: } \\
\text { (a) by a local legal practitioner, in connection } \\
\text { with the practice of law in this or any other } \\
\text { jurisdiction, or } \\
\text { (b) by an interstate legal practitioner, in } \\
\text { connection with the practice of law in this } \\
\text { jurisdiction. }\end{array}$ \\
\hline VIC & $\begin{array}{l}\text { Law Institute of } \\
\text { Victoria - } \\
\text { Professional } \\
\text { Conduct and } \\
\text { Practice Rules } \\
\text { (December 2005) }\end{array}$ & Nil. \\
\hline SA & $\begin{array}{l}\text { Law Society of } \\
\text { South Australia- } \\
\text { Rules of } \\
\text { Professional } \\
\text { Conduct \& } \\
\text { Practice (March } \\
\text { 2003) }\end{array}$ & $\begin{array}{l}\text { 44. Discrimination, Sexual Harassment and } \\
\text { Racial Vilification } \\
44.1 \text { Definitions } \\
\text { For the purpose of this Rule: } \\
\text { discrimination shall have the same meaning as it } \\
\text { does in: } \\
\text { - sections } 5,67 \text { [sic] and } 7 \mathrm{~A} \text { of the Sex } \\
\text { Discrimination Act } 1984 \text { (Cth); } \\
\text { - section } 9 \text { of the Racial Discrimination Act } \\
\\
1975 \text { (Cth); }\end{array}$ \\
\hline
\end{tabular}

${ }^{64}$ This table is based on one prepared by Carole Caple for the Law Council of Australia Equalising Opportunities in the Law Committee, 2007. 


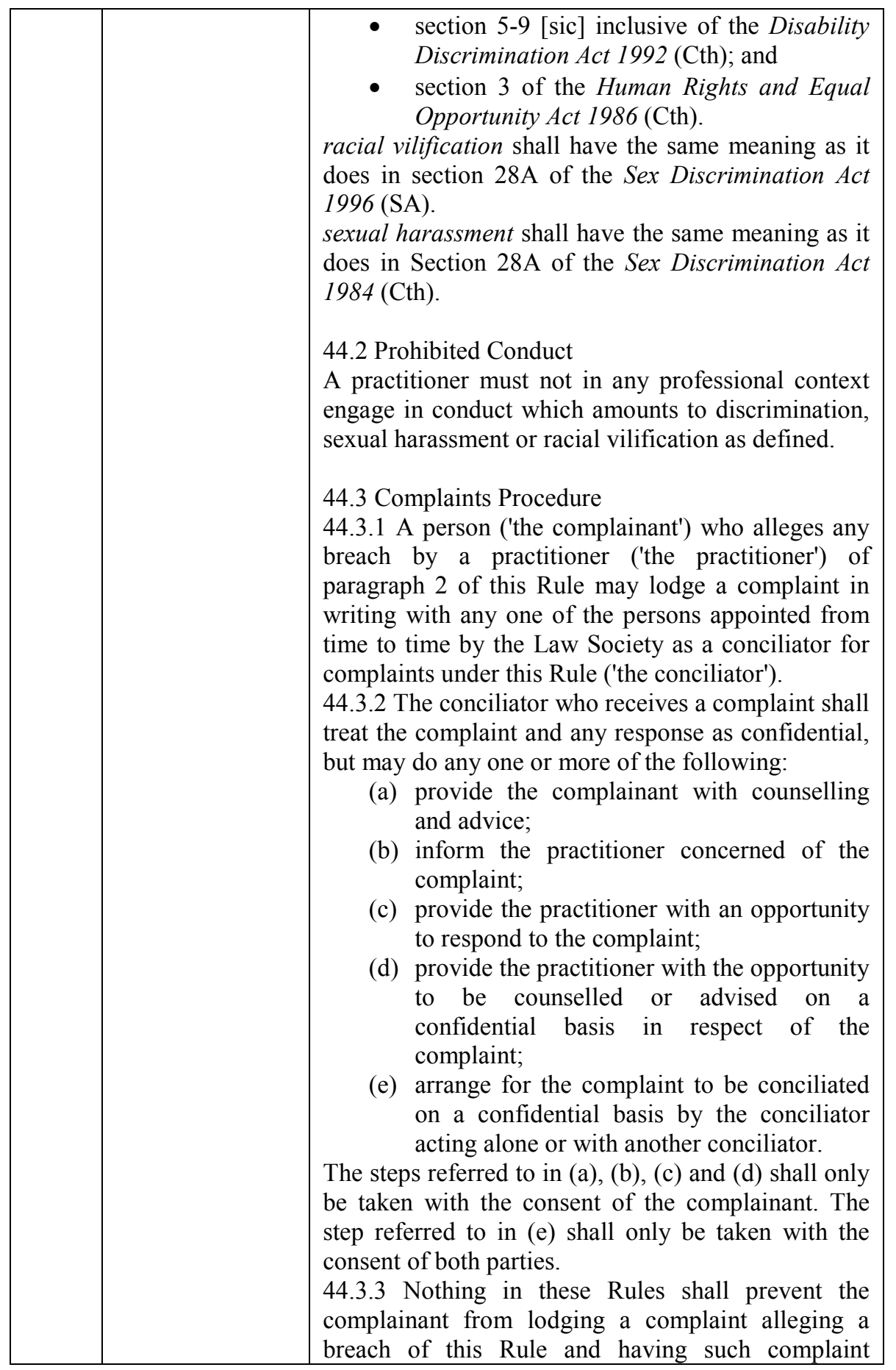




\begin{tabular}{|l|l|l|}
\hline & $\begin{array}{l}\text { treated as any other complaint by the prevailing } \\
\text { disciplinary procedure applying to the legal } \\
\text { profession in South Australia. }\end{array}$ \\
\hline WA & $\begin{array}{l}\text { Law Society of } \\
\text { Australia } \\
\text { Professional } \\
\text { Conduct Rules } \\
\text { December 2005) }\end{array}$ & $\begin{array}{l}\text { 20.5 } \\
\text { A practitioner must not discriminate against any } \\
\text { other practitioner by reason of the colour, race, } \\
\text { ethnic or national origins, gender, sexual orientation, } \\
\text { marital status, physical impairment or religious } \\
\text { beliefs of the other practitioner or any other ground } \\
\text { provided for by State or Commonwealth legislation. }\end{array}$ \\
$\begin{array}{l}\text { 20.6 } \\
\text { A practitioner must not, in the course of legal } \\
\text { practice, sexually harass any person. A practitioner is } \\
\text { taken to sexually harass another person if the } \\
\text { practitioner makes an unwelcome sexual advance, or } \\
\text { an unwelcome request for sexual favours, or engages } \\
\text { in other unwelcome conduct of a sexual nature and } \\
\text { the other person has a reasonable basis for believing } \\
\text { that by rejecting the advance, refusing the request or } \\
\text { taking objection to the conduct, the other person will } \\
\text { be disadvantaged in some way. } \\
\text { 20.7 practitioner must not, in the course of legal } \\
\text { A practice, engage in conduct which is not directed } \\
\text { towards a specific person, but is offensive or is likely } \\
\text { to offend a reasonable person because of its sexual } \\
\text { nature. }\end{array}$ \\
\hline
\end{tabular}

The Law Council of Australia's Equalising Opportunities in the Law Committee and the Law Council of Australia's Model Rules Working Party are discussing the wording of a new rule addressing these specific issues. While some may argue that the discrimination legislation and present Rules are framed broadly enough to cover matters such as unlawful discrimination, sexual harassment and workplace bullying, it is evident that specific mention of these matters can only serve to emphasise their importance to the profession. The recommendation is likely to be that any grievance provisions would be exactly the same as for any other breach of the Rules. In this way the behaviour is treated with an identical degree of severity as other censored behaviour. 


\section{B Education of the Profession}

The profession has not embraced the issue of compulsory education on these matters either. The HREOC Report made the following suggestions -

the results suggest that ongoing educational and prevention strategies are required to address sexual harassment. Employer groups, unions, employers and complaints handling agencies such as State and Territory equal opportunity agencies and HREOC all have a part to play in these ongoing activities... These findings suggest that, although many employers manage formal complaints adequately, there is significant room for improvement in the grievance procedures of some employers... Sexual harassment must be challenged if it is to be eliminated. Targets of sexual harassment must be assured that their complaint will be taken seriously and dealt with appropriately, or, as these survey results imply, they will not formally complain. Recognising that many targets of sexual harassment will not make a formal complaint, employers are encouraged to run strong prevention strategies and awareness campaigns in addition to providing strong complaints handling mechanisms. ${ }^{65}$

The Report adds that:

Employers need to be mindful of the social and organisational costs of sexual harassment. The nature of the relationship between workplace sexual harassment and staff turnover, particularly of the targets of harassment requires further research. One of the most striking findings in $\mathrm{A} \mathrm{Bad}$ Business was the large number of complainants who had resigned from their employment, or were dismissed, or were absent from the workplace where the sexual harassment occurred. The telephone survey did not ask interviewees whether they were still employed with the same employer where the harassment occurred. ${ }^{66}$

The results of the present Queensland Survey bear out these comments. The Queensland Law Society for example does not have a compulsory education requirement for discrimination and harassment as does its New South Wales counterpart. This appears true of societies in other States also, as the following table reveals. However, the new Compulsory Professional Development requirements being adopted in many of the jurisdictions make provision for compulsory training in core units. These core units tend to be umbrella areas that definitely include practice management. Discrimination and harassment fit easily within this broader description. The New South

\footnotetext{
${ }^{65}$ Human Rights and Equal Opportunity Commission, above n 2, 53-54.

${ }^{66}$ Ibid 54 .
} 
Wales Rules seem to be ahead in regard to this aspect of professional workplace training and indeed the specificity within the provisions provide a well-drafted statement that could be considered and perhaps replicated in other States.

Figure 6: Professional Education Provisions across Australia

\begin{tabular}{|c|c|c|}
\hline State & Source & Provision \\
\hline NSW & $\begin{array}{l}\text { Legal } \\
\text { Profession } \\
\text { Regulation } \\
2005\end{array}$ & $\begin{array}{l}\text { 176 Mandatory continuing legal education- } \\
\text { special requirement } \\
\text { (1) If the holder of a local practising certificate is } \\
\text { required to undertake continuing legal education, } \\
\text { that continuing legal education must include a } \\
\text { component relating to the management of the } \\
\text { practice of law that deals predominantly with the } \\
\text { following issues: } \\
\text { (a) the principles of equal employment opportunity, } \\
\text { (b) the law relating to discrimination and } \\
\text { harassment, } \\
\text { (c) occupational health and safety law, } \\
\text { (d) employment law, } \\
\text { (e) the management of legal practice consistent } \\
\text { with paragraphs (a)-(d). } \\
\text { (2) That component is to be undertaken at least } \\
\text { once in every compliance period, or such shorter } \\
\text { period as may be determined by the appropriate } \\
\text { Council, and is to comprise at least one unit in the } \\
\text { units of continuing legal education that the holder } \\
\text { of the practising certificate is required to undertake. } \\
\text { (3) In this clause: } \\
\text { compliance period' means: } \\
\text { (a) in relation to a person who was the holder } \\
\text { of a local practising certificate at } 2 \text { April } 2004: \\
\text { (i) the period starting on } 2 \text { April } 2004 \text { and } \\
\text { ending on } 31 \text { March } 2007 \text {, and } \\
\text { (ii) each further period of } 3 \text { years ending on } \\
\text { the third anniversary of the expiration of the } \\
\text { previous period, or } \\
\text { (b) in relation to a person who became or } \\
\text { becomes the holder of a local practising certificate } \\
\text { after } 2 \text { April } 2004 \text { : } \\
\text { (i) the period starting on the date the person }\end{array}$ \\
\hline
\end{tabular}




\begin{tabular}{|c|c|c|}
\hline & & $\begin{array}{l}\text { became or becomes the holder of a local practising } \\
\text { certificate and ending on } 31 \text { March in the year that } \\
\text { is } 3 \text { years after the start of the period, and } \\
\text { (ii) each further period of } 3 \text { years ending on } \\
\text { the third anniversary of the expiration of the } \\
\text { previous period. } \\
\text { 'continuing legal education' means continuing legal } \\
\text { education that the holder of a local practising } \\
\text { certificate is required to undertake under the } \\
\text { conditions attached to the certificate. } 67\end{array}$ \\
\hline ACT & $\begin{array}{l}\text { Law Society } \\
\text { of the } \\
\text { Australian } \\
\text { Capital } \\
\text { Territory }\end{array}$ & $\begin{array}{l}\text { Continuing Legal Education (CLE) is not } \\
\text { mandatory in the ACT. }\end{array}$ \\
\hline NT & $\begin{array}{l}\text { Law Society } \\
\text { Northern } \\
\text { Territory }\end{array}$ & $\begin{array}{l}\text { Northern Territory Continuing Professional } \\
\text { Development (CPD) in relation to gender issues } \\
\text { such as workplace discrimination is specifically } \\
\text { recognized under what is called 'Competency Area } \\
1 \text { ' or the 'Professional Practice Skill and Ethics' } \\
\text { component of the mandatory CPD scheme. } \\
\text { Practitioners have to accrue } 4 \text { points per year (out } \\
\text { of 12) in Competency Area } 1 \text {. Competency area } 1 \\
\text { also encompasses risk management, trust } \\
\text { accounting, advocacy and mediation. } \\
\text { CPD seminars are offered occasionally on gender } \\
\text { related issues. However, as there is more demand } \\
\text { for training in areas such as risk management, } \\
\text { seminars on these latter areas are more readily } \\
\text { available. }\end{array}$ \\
\hline QLD & $\begin{array}{l}\text { Queensland } \\
\text { Law Society }\end{array}$ & $\begin{array}{l}\text { The Queensland CPD Rules changed as of } 1 \text { April } \\
2008 \text { so that the core units are to be collected at the } \\
\text { rate of one point per core area per year. The core }\end{array}$ \\
\hline
\end{tabular}

\footnotetext{
${ }^{67}$ The Law Society of New South Wales Mandatory Continuing Legal Education Scheme (MCLE)

$<$ http://www.lawsociety.com.au/uploads/files/1170306460319_0.305729872908849.pdf $>$ at 8 June 2008.
} 


\begin{tabular}{|c|c|c|}
\hline & & $\begin{array}{l}\text { areas are Practical Legal Ethics, Practical } \\
\text { Management and Business Skills and Professional } \\
\text { Skills. }\end{array}$ \\
\hline TAS & $\begin{array}{l}\text { Law Society } \\
\text { of Tasmania }\end{array}$ & $\begin{array}{l}\text { Occasional Continuing Legal Education seminars } \\
\text { for the profession on subjects such as } \\
\text { discrimination legislation. }\end{array}$ \\
\hline \multirow[t]{2}{*}{ VIC } & $\begin{array}{l}\text { Judicial } \\
\text { College and } \\
\text { Aust Institute } \\
\text { of Judicial } \\
\text { Administrati } \\
\text { on }\end{array}$ & $\begin{array}{l}\text { The College provides training to judicial and } \\
\text { tribunal members. The bar readers' course includes } \\
\text { a session on discrimination and sexual harassment } \\
\text { rules. Ad hoc seminars are arranged by the } \\
\text { profession. }\end{array}$ \\
\hline & $\begin{array}{l}\text { Law Institute } \\
\text { of Victoria } \\
\text { Limited }\end{array}$ & $\begin{array}{l}\text { Continuing Professional Development Rules } 2007 \\
5.2 \text { Each CPD year, a practitioner must complete as } \\
\text { part of his or her CPD obligations at least } 1 \text { CPD } \\
\text { unit in each of the following fields: } \\
\text { (a) Ethics and Professional Responsibility } \\
\text { (b) Professional Skills } \\
\text { (c) Substantive Law } \\
\text { (d) Practice Management and Business Skills. (The } \\
\text { listing for this category includes Employment- } \\
\text { related equal opportunity and Employment-related } \\
\text { discrimination law. }{ }^{69}\end{array}$ \\
\hline WA & $\begin{array}{l}\text { The Law } \\
\text { Society of } \\
\text { Western } \\
\text { Australia }\end{array}$ & $\begin{array}{l}\text { The Board is asking that practitioners complete } 10 \\
\text { points across the three competency streams by } 31 \\
\text { March } 2009 \text {, in order to comply with the Policy and } \\
\text { apply for a practice certificate in } 2009 \text {. The } \\
\text { introduction of mandatory CPD is subject to the } \\
\text { Legal Profession Act being passed. }\end{array}$ \\
\hline
\end{tabular}

\footnotetext{
${ }^{68}$ Your Guide to Meeting CPD Requirements in Queensland, $<$ http:/www.qls.com.au/content/lwp/wcm/resources/file/ebe1f6047d55f53/08CPDChanges2.p df $>$ at 8 June 2008.

${ }^{69}$ Continuing Professional Development Rules 2007 (CPD Rules 2007) http://www.liv.asn.au/regulation/arf/about/\#Heading3 at 8 June 2008.
} 


\begin{tabular}{|l|l|}
\hline & $\begin{array}{l}\text { Competency 1 = Legal skills \& practice } \\
\text { Competency 2 }=\text { Values } \\
\text { Competency 3 = Legal knowledge }\end{array}$ \\
\hline
\end{tabular}

Employer of Choice Awards are also effective in educating the profession and promoting change. The Queensland Law Society runs such a program through its Equalising Opportunities in the Law Committee. Industry programs instigated by the Federal Government's Equal Opportunity for Women in the Workplace Agency have also had a positive role in educating, and rewarding organisations that perform well in increasing opportunities for women in the workplace. Legal firms have been prominent amongst the award recipients. $^{71}$

\section{CONCLUSION}

The more recent reports are suggesting that the answer to many of the work issues highlighted in this study lies in a better overall work/life balance, particularly in the large city legal firms. ${ }^{72}$ Improved work culture would be likely to benefit the whole legal workforce and in so doing would be especially beneficial to women. Two related initiatives - the attempt to create a more inclusive work environment, and enhanced efforts to foster an awareness of discrimination, harassment and bullying, are a key to change. There would seem to be still an enormous amount of work required to change the ethos of the profession, and in doing so enhance the work experience of women lawyers. In particular, no work as yet has been done on the last two recommendations of the Report. These are 'the development of equal employment guidelines for law firms' and 'best practice guidelines for enterprise agreements in the law firms ${ }^{73}$ These very practical aspects will be most important in the future.

\footnotetext{
${ }^{70}$ The Law Society of Western Australia CPD <http://www.cpdlswa.com.au/03_about.html $>$ at 8 June 2008.

${ }^{71}$ Equal Opportunity for Women in the Workplace Agency, EOWA Employer of Choice for Women (2008) Australian Government: Equal Opportunity for Women in the Workplace Agency $<$ http://www.eowa.gov.au/EOWA_Employer_Of_Choice_For_Women.asp $>$ at 1 May 2008.

${ }^{72}$ For a full bibliography on this issue see Hutchinson, above $\mathrm{n} 14$.

${ }^{73}$ Queensland Law Society Equalising Opportunities in the Law Committee, above n 1, 46-47.
} 